\title{
Modeling heavy metal release in the epiphytic lichen Evernia prunastri
}

\author{
Andrea Vannini ${ }^{1} \cdot$ Luca Paoli $^{2} \cdot$ Riccardo Fedeli $^{1}$ - Sharon Kwambai Kangogo ${ }^{1} \cdot$ Massimo Guarnieri $^{1}$. \\ Stefania Ancora ${ }^{3} \cdot$ Fabrizio Monaci $^{1} \cdot$ Stefano Loppi ${ }^{1}$
}

Received: 30 May 2020 / Accepted: 18 January 2021 / Published online: 28 January 2021

(C) The Author(s) 2021

\begin{abstract}
In this study, the release of $\mathrm{Cu}^{2+}$ and $\mathrm{Zn}^{2+}$ was investigated and modeled in the epiphytic lichen Evernia prunastri. Samples were incubated with solutions containing these metals at ecologically relevant concentrations $(10$ and $100 \mu \mathrm{M})$ and then transplanted to a remote area and retrieved after 1, 2, 3, 6, 12, and 18 months. The results showed that, after 12 months, all samples faced similar metal reductions of ca. $80-85 \%$, but after this period, all the involved processes seem to be no longer capable of generating further reductions. These results suggest that the lichen E. prunastri can provide information about environmental improvements after exposure to high or very high pollution levels in a relatively short period of time.
\end{abstract}

Keywords Air pollution $\cdot$ Bioaccumulation $\cdot$ Biomonitoring $\cdot \mathrm{Cu} \cdot$ Environmental recovery $\cdot \mathrm{Zn}$

\section{Introduction}

Lichens have long been considered good bioindicators of air quality and a very effective biological tool to evaluate the environmental availability of trace metals (Bačkor and Loppi 2009). The content of heavy metals in lichens, which is known to be proportional to their content in bulk deposition (Loppi and Paoli 2015), is the result of a dynamic process in which both accumulation and release events occur, until an equilibrium with the surrounding environment is reached (Nieboer et al. 1978).

Changes in the metal content of lichens as a consequence of changes (either increases or reductions) in metal environmental availability require some time to occur (called "remembrance

Responsible Editor: Gangrong Shi

Stefano Loppi

stefano.loppi@unisi.it

Department of Life Science, University of Siena, I-53100 Siena, Italy

2 Department of Biology, University of Pisa, I-56126 Pisa, Italy

3 Department of Physics, Earth and Environmental Sciences, University of Siena, I-53100 Siena, Italy time," see Reis et al. 1999) that is generally assumed to be shorter for accumulation events than for releases. In fact, when lichens face increased heavy metal availability (e.g., when they are transplanted to polluted areas), they may require up to 12 months to reach an equilibrium with the new environment (Godinho et al. 2008; Kularatne and De Freitas 2013; Paoli et al. 2018a), while when metal availability is decreased, lichens require a much longer time, up to 5 years, to release them and reach a new equilibrium with the surrounding environment (Walther et al. 1990; Nieboer and Richardson 1981). Nevertheless, when metals are provided in ionic form dissolved in water, lichens require a much shorter time (from a few minutes to hours) to reach an equilibrium (Loppi et al. 2020; Paoli et al. 2018b), but also in this case, metal ion release requires a longer, although undetermined, time (Loppi et al. 2020). Although the dynamic of accumulation of heavy metals in lichens is well documented (Bačkor and Loppi 2009), information about their release is minimal, and studies dedicated to model the time required by lichens to release the accumulated metals are very scanty.

In this study, the modeling of $\mathrm{Cu}^{2+}$ and $\mathrm{Zn}^{2+}$ releases provided in ionic form was investigated in the lichen Evernia prunastri, with the hypothesis that 18 months are sufficient for "contaminated" thalli to reach an equilibrium with a relatively unpolluted environment. 


\section{Materials and Methods}

\section{Sample collection}

Samples of the lichen species Evernia prunastri (L.) Ach. were collected in a remote area of the Siena Province $\left(43^{\circ}\right.$ $11^{\prime} 60^{\prime \prime} \mathrm{N}, 11^{\circ} 21^{\prime} 33^{\prime \prime} \mathrm{E}, 310 \mathrm{~m}$ a.s.l.), located far from any local pollution source. Lichen thalli were harvested from the branches of Prunus spinosa shrubs taking care to collect only those with lobes longer than $5 \mathrm{~cm}$ (adult thalli). This species was selected being widely used in biomonitoring studies (Loppi et al. 1998; Vannini et al. 2017) and for its documented ability to accumulate heavy metals (Loppi and Paoli 2015). In the laboratory, lichen thalli were cleaned from any extraneous material (e.g., other lichen species, mosses, and bark residues) using plastic tweezers, washed three times for $5 \mathrm{~s}$ with deionized water to remove superficial dust then let airdry overnight.

\section{Experimental}

The whole lichen pool was randomly subdivided into five batches, each consisting of $12.25 \mathrm{~g}$ of lichen material and subsequently treated as follows: four batches were separately incubated (200:50 w:v) for $1 \mathrm{~h}$ with $\mathrm{Cu}^{2+}$ and $\mathrm{Zn}^{2+} 10$ and $100 \mu \mathrm{M}$ solutions obtained from chloride salts. The $\mathrm{pH}$ of the solutions was adjusted to 5.5 to maximize metal uptake (Chettri et al. 1997). The last batch was incubated with deionized water (pH adjusted to 5.5) and used as control. After treatment, samples were quickly rinsed three times in deionized water to remove metal amounts simply deposited on the surface of thalli and then let air-dry to allow for a possible later metal uptake (Brown and Beckett 1985).

Each batch of samples was randomly subdivided in seven subsets having a weight of $1.75 \mathrm{~g}$ from which seven "lichen bags" of approximately $0.25 \mathrm{~g}$ were prepared (statistical replicates). The lichen material was loosely wrapped inside plastic net (mesh $1 \mathrm{~cm}^{2}$ ), closing them at the two extremities using plastic wire. One of these seven subsets was air-dried overnight in a climatic chamber at $16{ }^{\circ} \mathrm{C}$ and $55 \% \mathrm{RH}$ (residual water content $<10 \%$ ) and then stored at $-20{ }^{\circ} \mathrm{C}$ until analyses and later used as a starting point for the evaluation of the elemental release (month 0 ). Treatment concentrations, selected in order to generate metal uptake in lichens (Paoli et al. 2018b), are within the range of ecologically relevant metal concentrations in polluted environments (Chettri et al. 1997).

\section{Lichen exposure}

The lichen bags were exposed in a new and relatively unpolluted environment located in a rural area of the Grosseto Province ( $\left.42^{\circ} 41^{\prime} 23^{\prime \prime} \mathrm{N}, 11^{\circ} 20^{\prime} 05^{\prime \prime} \mathrm{E}\right)$ at ca. $2 \mathrm{~m}$ from the ground, during October 2017. This site was selected being protected from vandalism and to allow for an easy check of the samples during this long-lasting experiment. Samples were retrieved after $1,2,3,6,12$, and 18 months from the transplantation. In the laboratory, samples were removed from bags, air-dried overnight in a climatic chamber at $16{ }^{\circ} \mathrm{C}$ and $55 \% \mathrm{RH}$ and then stored at $-20{ }^{\circ} \mathrm{C}$ until analyses. Table 1 shows the monthly rainfall at the exposure site during the study period.

\section{Chemical analysis}

Prior to mineralization, each sample was pulverized in liquid nitrogen with a ceramic mortar and pestle. Approximately $200 \mathrm{mg}$ of lichen powder was mineralized in a MW digestion system (Milestone Ethos 1) with $7 \mathrm{~mL}$ of $\mathrm{HNO}_{3}$ and $3 \mathrm{~mL}$ of $\mathrm{H}_{2} \mathrm{O}_{2}$ using hermetic Teflon vessels at $130{ }^{\circ} \mathrm{C}$ and high pressure (100 bar). Depending on the concentration, the mineralized and diluted solutions (up to $50 \mathrm{~mL}$ ) were analyzed either by inductively coupled plasma atomic emission spectrometry (ICP-AES, Optima 5300 dv; Perkin Elmer) or by transversely heated graphite furnace (THGA) with longitudinal Zeemaneffect background corrector atomic absorption spectrometry (AAnalyst 800; Perkin Elmer). The results are expressed on a dry weight basis $\left(\mu \mathrm{g} \mathrm{g}^{-1} \mathrm{dw}\right)$. Analytical quality was checked by analyzing the Standard Reference Material IAEA-336 "lichen," which indicated recoveries in the range $97-101 \%$. The precision of the analytical procedure was

Table 1 Total monthly rainfall at the exposure site during the study period

\begin{tabular}{llll}
\hline Time (months) & Month & Year & Rain (mm) \\
\hline 1 & October & 2017 & 3.4 \\
2 & November & 2017 & 25.4 \\
3 & December & 2017 & 58.6 \\
4 & January & 2018 & 59.6 \\
5 & February & 2018 & 141.8 \\
6 & March & 2018 & 192.8 \\
7 & April & 2018 & 30.6 \\
8 & May & 2018 & 135.8 \\
9 & June & 2018 & 102.2 \\
10 & July & 2018 & 3 \\
11 & August & 2018 & 58.6 \\
12 & September & 2018 & 6.8 \\
13 & October & 2018 & 94.6 \\
14 & November & 2018 & 129.2 \\
15 & December & 2018 & 45.8 \\
16 & January & 2019 & 78 \\
17 & February & 2019 & 64.2 \\
18 & March & 2019 & 6.8 \\
\hline
\end{tabular}


estimated by the coefficient of variation of four replicates that was within $5 \%$ for both elements.

\section{Statistics}

To account for possible temporal variations in the atmospheric deposition at the exposure site, results were reported as ratio between exposed samples to their respective temporal control (exposed-to-control, EC ratio). Statistically significant differences between exposed and control samples as well as variations of the EC ratio across time were checked using the Wilcoxon signed-rank test, applying a correction for multiple testing according to Benjamini and Hochberg (1995).

Non-linear regression analysis (exponential, power, and logarithmic) was run to model the relationship between EC values and exposure time. The best fitting was sought comparing $R^{2}$ and AIC (Akaike Information Criterion) values. Equation coefficients were used to model the release rates of $\mathrm{Cu}$ and $\mathrm{Zn}\left(\mathrm{EC}\right.$ month $\left.^{-1}\right)$ by their derivatives. All calculations were run using the free software R (R Core Team 2020).

\section{Results}

During the exposure, control samples showed $\mathrm{Cu}$ and Zn concentrations (5.6 \pm 0.6 and $40.2 \pm 3.8 \mu \mathrm{g} \mathrm{g}^{-1}$, respectively)

a

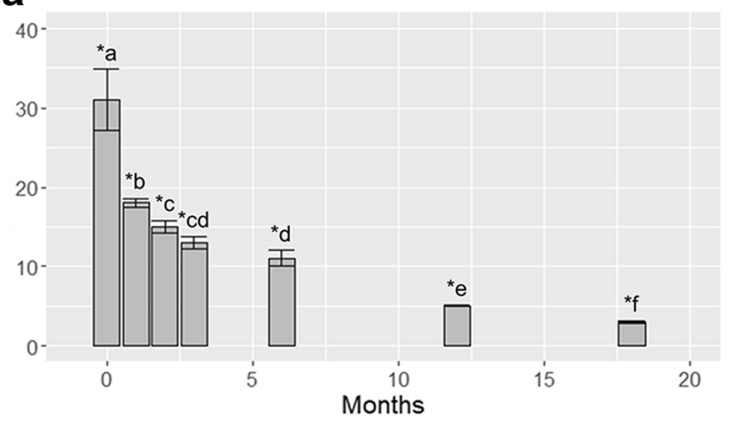

\section{C}

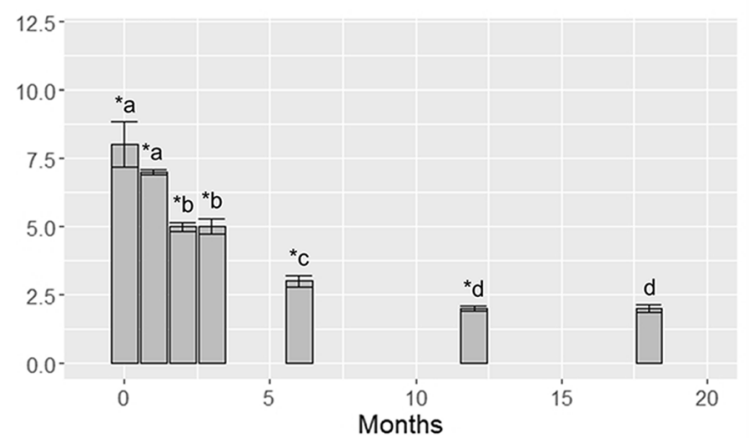

Fig. 1 Accumulation values (EC ratio) (mean \pm SE) in samples of E. prunastri treated with $\mathrm{Cu} 10 \mu \mathrm{M}$ (a), Cu $100 \mu \mathrm{M}$ (b), Zn $10 \mu \mathrm{M}$ (c), $\mathrm{Zn} 100 \mu \mathrm{M}(\mathbf{d})$, and transplanted in a clean environment for $0,1,2,3,6$, 12 , and 18 months. The asterisk indicates statistically significant not exceeding those $\left(6 \pm 0.6\right.$ and $\left.43 \pm 4 \mu \mathrm{g} \mathrm{g}^{-1}\right)$ reported for the lichen E. prunastri from background areas (Cecconi et al. 2019). Results of the temporal release of $\mathrm{Cu}$ and $\mathrm{Zn}$ from samples of E. prunastri after their transplantation in the remote environment are shown in Fig. 1. Statistically significant $(p<0.05)$ releases of $\mathrm{Cu}$ were evident already after 1 month. In detail, after the treatment with $10 \mu \mathrm{M}$ samples showed a decrease by $40 \%$ after 1 month, by about $65 \%$ after 6 months and finally by about $91 \%$ after 18 months. Continuous statistically significant $(p<0.05)$ decreases across time were observed. After the treatment with $100 \mu \mathrm{M}$, samples showed similar decreasing trends, with reductions approximately by $56 \%$ after 1 month, by $80 \%$ after 6 months and by $84 \%$ after 18 months; no statistical $(p>0.05)$ differences were detected from 6 to 18 months from the transplantation.

Both $\mathrm{Zn}$ exposures showed very similar release trends after transplantation into the new environment irrespective of the treatment. Specifically, $\mathrm{Zn}$ showed statistically significant $(p$ $<0.05$ ) releases starting after 2 months, with decreases in the range $39 \%$ for samples treated with $10 \mu \mathrm{M}$ and $65 \%$ for those treated with the $100 \mu \mathrm{M}$. After 6 months, samples exposed to $10 \mu \mathrm{M}$ and $100 \mu \mathrm{M}$ showed significant $(p<0.05)$ reductions by $69 \%$ and $75 \%$, respectively, while after 18 months, a similar average reduction by ca. $83 \%$ was evident. Statistically significant $(p<0.05)$ differences between 6 and 18 months were observed for both exposures.

\section{b}

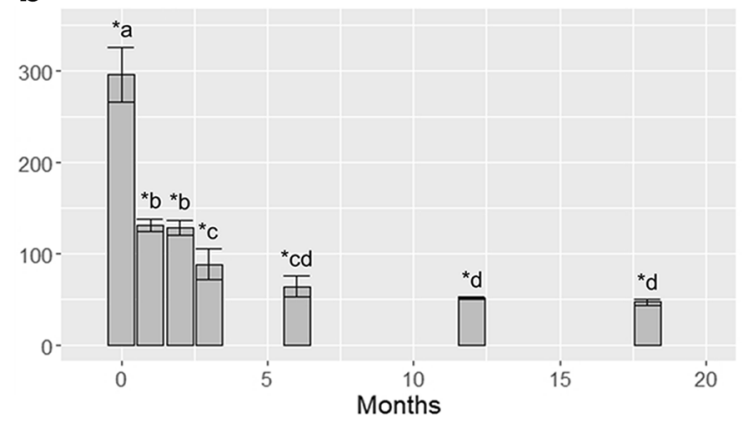

d

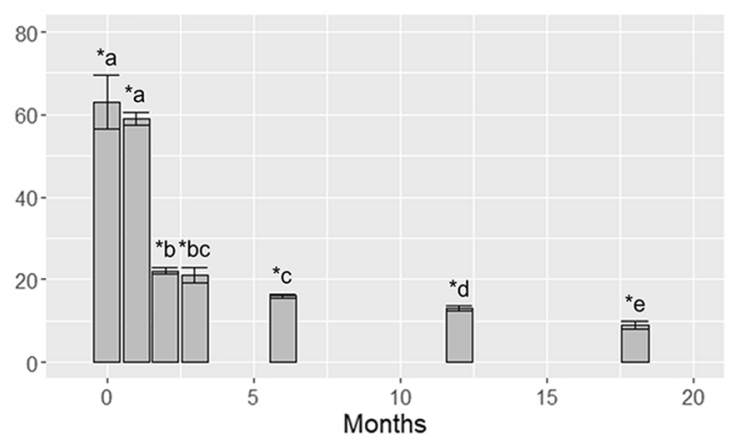

differences between treated and control samples $(p<0.05)$. Different letters indicate statistically significant differences between EC values across time $(p<0.05)$ 


\section{a}

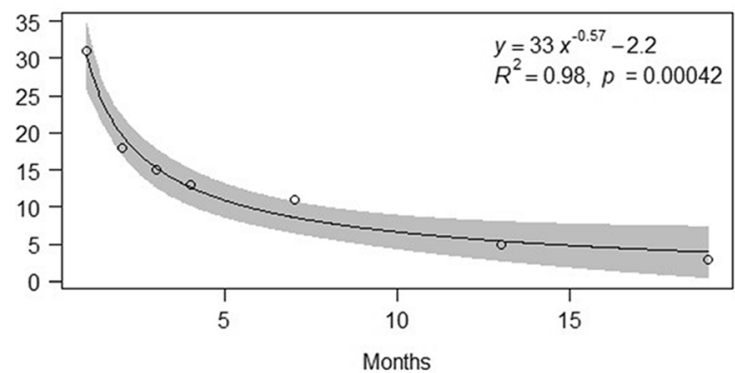

C

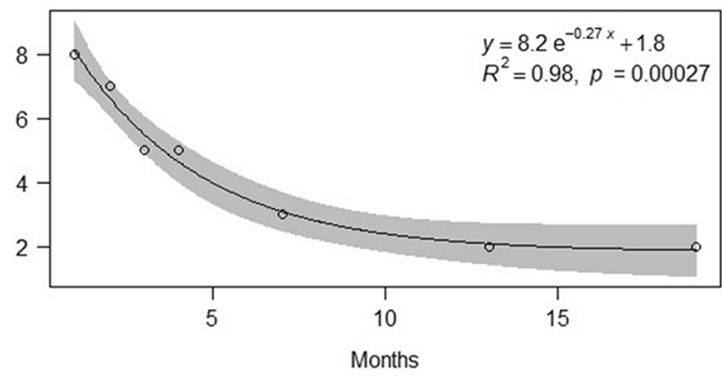

Fig. 2 Exponential and power regressions of accumulation values (average of the EC ratio) across time in samples of E. prunastri treated with $\mathrm{Cu} 10 \mu \mathrm{M}$ (a), $\mathrm{Cu} 100 \mu \mathrm{M}(\mathbf{b}), \mathrm{Zn} 10 \mu \mathrm{M}$ (c), Zn $100 \mu \mathrm{M}$ (d), and

After 18 months from the transplantation, only samples exposed to $\mathrm{Zn} 10 \mu \mathrm{M}$ did not show any statistically significant $(p>0.05)$ difference compared with control samples.

Samples treated with $\mathrm{Cu}$ showed the best relationship between $\mathrm{EC}$ values and transplantation time with the power regression
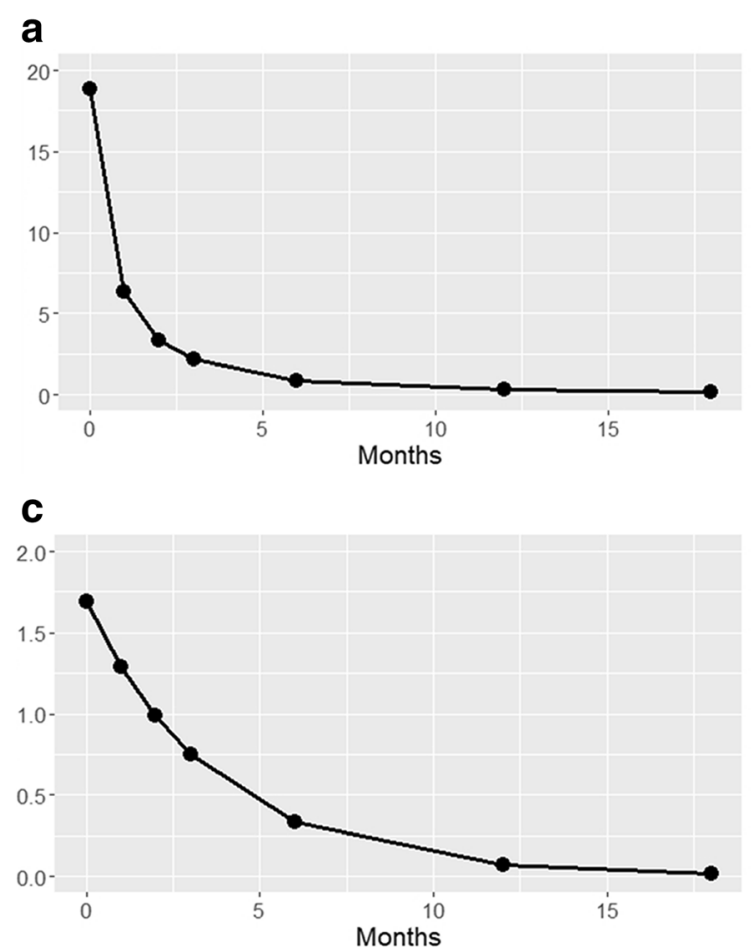

\section{b}

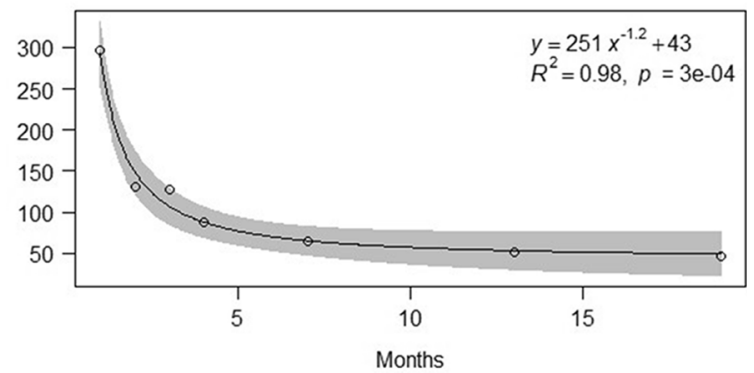

d

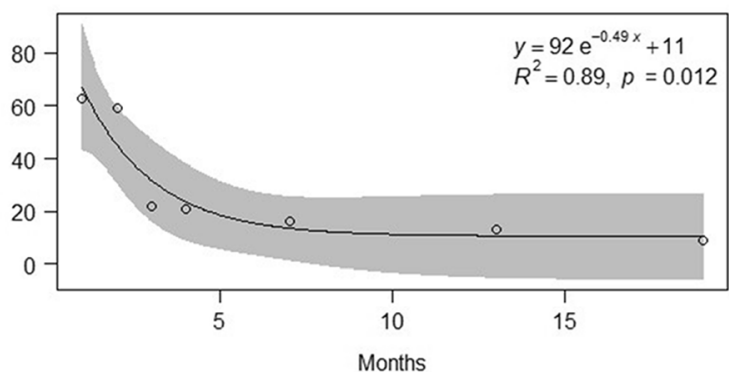

transplanted in a clean environment for $0,1,2,3,6,12$, and 18 months. The gray area indicates $95 \%$ confidence interval

model, while those exposed to $\mathrm{Zn}$ with the exponential regression model (Fig. 2). The results of the calculated release rates for each sample at all exposure time are presented in Fig. 3. Samples treated with $\mathrm{Cu}$ showed abrupt decreases in their release rates already after 1 month from the transplantation and irrespective

\section{b}

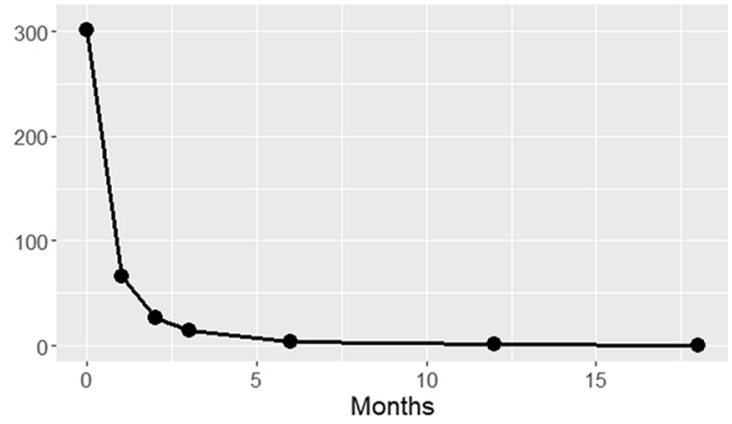

d

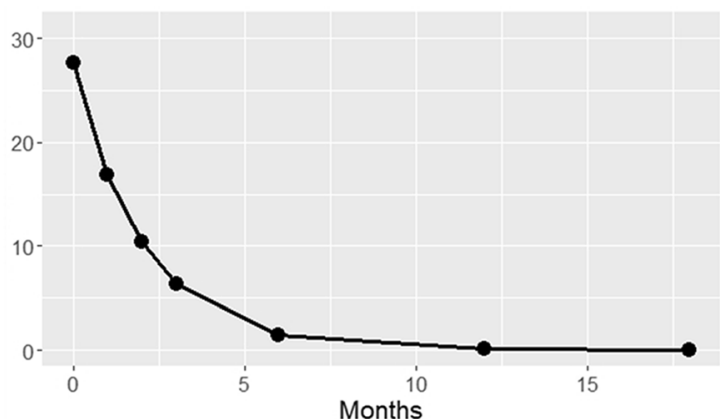

Fig. 3 Release rates $\left(\mathrm{EC}\right.$ month $^{-1}$ ) in samples of E. prunastri treated with $\mathrm{Cu} 10 \mu \mathrm{M}(\mathbf{a}), \mathrm{Cu} 100 \mu \mathrm{M}(\mathbf{b}), \mathrm{Zn} 10 \mu \mathrm{M}(\mathbf{c}), \mathrm{Zn} 100 \mu \mathrm{M}(\mathbf{d})$ after their transplantation in a clean environment for $0,1,2,3,6,12$, and 18 months 
of the treatment, while those exposed to $\mathrm{Zn}$ showed more gradual reductions across time. Starting from 12 months from the transplantation, the release rates reached almost constant values.

\section{Discussion}

This study investigated the release dynamics of accumulated ionic metals, namely, $\mathrm{Cu}^{2+}$ and $\mathrm{Zn}^{2+}$, in thalli of the lichen E. prunastri after their transplantation into a relatively unpolluted environment. Our results indicate relative element releases, expressed in terms of EC ratios, across time, with losses already evident after the first 1-2 months from the transplantation; moreover, after 18 months, all samples showed similar $85 \%$ reductions. Only samples exposed to $\mathrm{Zn} 10 \mu \mathrm{M}$ reached background values, while the others still retained important amounts of metals, with EC values suggestive of a severe accumulation (Cecconi et al. 2019). We argue that the complete release of $\mathrm{Zn}$ from lichen samples treated with $10 \mu \mathrm{M}$ solutions of this metal may be related to its limited accumulation after the treatment (month 0 ), less than $75 \%$ of the accumulated $\mathrm{Cu}$ at the same exposure time and level. This result is further confirmed by the closer approach to background values for samples treated with $\mathrm{Zn} 100 \mu \mathrm{M}$ than for those treated with the same amount of $\mathrm{Cu}$.

A decrease in the elemental content in lichens may occur following different mechanisms, as in the succession of wetting and drying cycles (Nieboer and Richardson 1981), the accumulation of other metals with higher affinity for the extracellular bindings sites, leading to the displacement of weaker ions (Paoli et al. 2018b), or the biomass increase (growth) of the thalli which may cause dilutions in their respective contents (Bargagli and Mikhailova 2002). Nevertheless, metal release from lichens may also occur following their excretion onto the thallus surface after their complexation by oxalates and secondary compounds (Sarret et al. 1998), which may subsequently be dislodged by the action of rainfall, similar to insoluble particulate matter deposition (Brown and Brown 1991). We may argue that a fast $\mathrm{Cu}$ release from lichen thalli may be due to this latter mechanism, which acts to limit the bioavailability of this metal as much as possible, being $\mathrm{Cu}$ highly toxic for lichens at elevated concentrations (Bačkor and Loppi 2009).

Information about the time that lichens require to accomplish the complete release of their accumulated metal content is very limited; nevertheless, consistently with our results, field studies indicated that lichens may require more than 18 months to release their accumulated metals following environmental improvements. Specifically, Paoli et al. (2018a) reported that samples of the lichen Flavoparmelia caperata collected from the surroundings of a landfill and transplanted for 1 year into an unpolluted site, faced only slight decreases of ca. $30 \%$, and speculated that at least 2 years are necessary for lichens exposed to high amounts of depositions to reach background concentrations. Similar results (half memory time of 200 to 600 days) were calculated for thalli of Parmelia sulcata transplanted nearby a power plant (Reis et al. 1999) and observed (2-4 years) in thalli of Parmotrema praesorediosum and Ramalina stenospora after the stop of industrial emissions (Walther et al. 1990). Moreover, the results reported by Walther et al. (1990) for R. stenospora are consistent with those observed in our study for samples treated with Zn $10 \mu \mathrm{M}$, with similar concentrations of ca. $100 \mu \mathrm{g} / \mathrm{g}$ and a similar time of about 1 year to reach steady background values. On the other hand, samples of $F$. caperata transplanted for 6 months in a polluted area and then brought back to the reference site for 3 months showed the complete release of the previously accumulated $\mathrm{Cu}$ and $\mathrm{Zn}$ (Godinho et al. 2011).

The results of the release rates suggest that after 12 months any further metal reduction is negligible. We argue that most of the remaining non-released fraction (about $15-20 \%$ of the accumulated metals) may be bound to the cell wall exchange sites, as highlighted by Loppi et al. (2020). This fraction can be regarded as the "memory" of the past pollution event (Reis et al. 2002; Boulyga et al. 2003; Dalvand et al. 2016). These results have important implications for biomonitoring since, if on the one side confirm that lichens do reflect an averagely integrated time period of exposure, on the other side they indicate that under certain circumstances they may not at all reflect the current pollution level at a site.

\section{Conclusions}

Our results allowed to accept the working hypothesis that 18 months are a sufficient amount of time for lichen samples exposed to ecologically relevant concentrations (10 and $100 \mu \mathrm{M})$ of $\mathrm{Cu}$ and $\mathrm{Zn}$ ions to reflect an improved environmental simulation. After 12 months, all samples showed similar metal reductions of ca. $80-85 \%$, but after this period, all the involved processes seem to be no longer capable of generating further reductions. These results suggest that the lichen E. prunastri can provide information about environmental improvements after exposure to high or very high pollution levels in a relatively short period of time. Nevertheless, the temporal dimension of the outcomes of transplant studies using this species, usually involving exposure periods of 1-6 months, has to be evaluated carefully.

Author contributions SL conceived and designed the experiments; AV, LP, RF SK, SA performed the experiments; SL and AV analyzed the data; MG, FM contributed analysis tools; AV wrote the paper, SL supervised the text; all authors read and approved the final manuscript.

Funding Open Access funding provided by Università degli Studi di Siena.

Data availability The datasets used and/or analyzed during the current study are available from the corresponding author on reasonable request 


\section{Compliance with ethical standards}

Competing interests The authors declare that they have no competing interests.

\section{Ethics approval and consent to participate Not applicable.}

\section{Consent for publication Not applicable.}

Open Access This article is licensed under a Creative Commons Attribution 4.0 International License, which permits use, sharing, adaptation, distribution and reproduction in any medium or format, as long as you give appropriate credit to the original author(s) and the source, provide a link to the Creative Commons licence, and indicate if changes were made. The images or other third party material in this article are included in the article's Creative Commons licence, unless indicated otherwise in a credit line to the material. If material is not included in the article's Creative Commons licence and your intended use is not permitted by statutory regulation or exceeds the permitted use, you will need to obtain permission directly from the copyright holder. To view a copy of this licence, visit http://creativecommons.org/licenses/by/4.0/.

\section{References}

Bačkor M, Loppi S (2009) Interactions of lichens with heavy metals. Biol Plantarum 53:214-222. https://doi.org/10.1007/s10535-009-0042-y

Bargagli R, Mikhailova I (2002) Accumulation of inorganic contaminants. In: Nimis PL, Scheidegger C, Wolseley PA (eds) Monitoring with lichens - monitoring lichens. NATO Science Series (Series IV: Earth and Environmental Sciences), vol 7. Springer, Dordrecht, pp 65-84

Benjamini Y, Hochberg Y (1995) Controlling the false discovery rate: a practical and powerful approach to multiple testing. Journal of the Royal statistical society: series B (Methodological) 57(1):289-300

Boulyga SF, Desideri D, Meli MA, Testa C, Becker JS (2003) Plutonium and americium determination in mosses by laser ablation ICP-MS combined with isotope dilution technique. Int J Mass Spectrom 226: 329-339. https://doi.org/10.1016/S1387-3806(03)00024-1

Brown DH, Beckett RP (1985) The role of the cell wall in the intracellular uptake of cations by lichens. In: Brown DH (ed) Lichen physiology and cell biology. Plenum Press, New York, pp 247-258

Brown DH, Brown RM (1991) Mineral cycling and lichens: the physiological basis. The Lichenologist 23:293-307. https://doi.org/10. 1017/S0024282991000440

Cecconi E, Fortuna L, Benesperi R, Bianchi E, Brunialti G, Contardo T, Di Nuzzo L, Frati L, Monaci F, Munzi S, Nascimbene J, Paoli L, Ravera S, Vannini A, Giordani P, Loppi S, Tretiach M (2019) New interpretative scales for lichen bioaccumulation data: the Italian proposal. Atmosphere 10:136. https://doi.org/10.3390/atmos10030136

Chettri MK, Sawidis T, Zachariadis GA, Stratis JA (1997) Uptake of heavy metals by living and dead Cladonia thalli. Environ Exp Bot 37:39-52. https://doi.org/10.1016/S0098-8472(96)01023-4

Dalvand A, Jahangiri A, Iranmanesh J (2016) Introduce lichen Lepraria incana as biomonitor of Cesium-137 from Ramsar, northern Iran. J Environ Radioact 160:36-41. https://doi.org/10.1016/j.jenvrad. 2016.04.018

Godinho RM, Wolterbeek HT, Verburg T, Freitas MC (2008) Bioaccumulation behaviour of transplants of the lichen Flavoparmelia caperata in relation to total deposition at a polluted location in Portugal. Environ Pollut 151:318-325. https://doi.org/ 10.1016/j.envpol.2007.06.034

Godinho RM, Verburg TG, Freitas MC, Wolterbeek HT (2011) Dynamics of element accumulation and release of Flavoparmelia caperata during a long-term field transplant experiment. Int $\mathbf{J}$ Environ Health 5:49-59. https://doi.org/10.1504/IJENVH.2011. 039855

Kularatne KIA, De Freitas CR (2013) Epiphytic lichens as biomonitors of airborne heavy metals in the Greater Auckland Region, New Zealand. Environ Exp Bot 88:24-32. https://doi.org/10.1016/j. envexpbot.2012.02.010

Loppi S, Paoli L (2015) Comparison of the trace element content in transplants of the lichen Evernia prunastri and in bulk atmospheric deposition: a case study from a low polluted environment (C Italy). Biologia 70:460-466. https://doi.org/10.1515/biolog-2015-0053

Loppi S, Pacioni G, Olivieri N, Di Giacomo F (1998) Accumulation of trace metals in the lichen Evernia prunastri transplanted at biomonitoring sites in central Italy. Bryologist 101:451-454. https://doi.org/ $10.2307 / 3244187$

Loppi S, Di Lucia A, Vannini A, Ancora S, Monaci F, Paoli L (2020) Uptake and release of copper ions in epiphytic lichens. Biologia. 75: 1547-1552. https://doi.org/10.2478/s11756-020-00522-x

Nieboer E, Richardson DHS (1981) Lichens as monitors of atmospheric deposition. Ann Arbor Science Publishers, Ann Arbor, MI, pp 339-388

Nieboer E, Richardson DHS, Tomassini FD (1978) Mineral uptake and release by lichens: an overview. Bryologist 81:226-246. https://doi. org/10.2307/3242185

Paoli L, Vannini A, Fačkovcová Z, Guarnieri M, Bačkor M, Loppi S (2018a) One year of transplant: is it enough for lichens to reflect the new atmospheric conditions? Ecol Indic 88:495-502. https://doi. org/10.1016/j.ecolind.2018.01.043

Paoli L, Vannini A, Monaci F, Loppi S (2018b) Competition between heavy metal ions for binding sites in lichens: implications for biomonitoring studies. Chemosphere 199:655-660. https://doi.org/10. 1016/j.chemosphere.2018.02.066

R Core Team (2020) R: A Language and Environment for Statistical Computing. R Foundation for Statistical Computing, Wien, Austria. Available at: https://www.R-project.org/

Reis MA, Alves LC, Freitas MC, Van Os B, Wolterbeek HT (1999) Lichens (Parmelia sulcata) time response model to environmental elemental availability. Sci Total Environ 232(1-2):105-115. https:// doi.org/10.1016/S0048-9697(99)00113-8

Reis MA, Alves LC, Freitas MC, van Os B, De Goeij J, Wolterbeek HT (2002) Calibration of lichen transplants considering faint memory effects. Environ Pollut 120:87-95. https://doi.org/10.1016/s02697491(02)00131-8

Sarret C, Manceau A, Cuny D, van Haluwyn C, Déruelle S, Hazemann JL, Soldo Y, Eybert-Berard L, Menthonnex JJ (1998) Mechanisms of lichen resistance to metallic pollution. Environ Sci Technol 32(21):3325-3330. https://doi.org/10.1021/es970718n

Vannini A, Paoli L, Nicolardi V, Di Lella LA, Loppi S (2017) Seasonal variation of intracellular trace elements content and physiological parameters in the lichen Evernia prunastri transplanted to an urban environment. Acta Bot Croat 76:171-176. https://doi.org/10.1515/ botcro-2017-0007

Walther DA, Ramelow GJ, Beck JN, Young JC, Callahan JD, Maroon MF (1990) Temporal changes in metal levels of the lichens Parmotrema praesorediosum and Ramalina stenospora, southwest Louisiana. Water Air Soil Pollut 53:189-200. https://doi.org/10. 1007/BF00155003

Publisher's note Springer Nature remains neutral with regard to jurisdictional claims in published maps and institutional affiliations. 